\title{
INDEKS MASSA TUBUH (IMT) DAN RASIO LINGKAR PINGGANG DAN PANGGUL (RLPP) SEBAGAI PREDIKTOR HIPERTENSI PADA LANJUT USIA
}

\author{
Yuriza Agustiningrum, Nur Lathifah Mardiyanti \\ Program Studi Ilmu Gizi Fakultas Ilmu Kesehatan Universitas Muhammdiyah Surakarta
}

\begin{abstract}
Elderly, Hypertension, Body Mass Index, Waist Circumference and Hip. The problem of hypertension is one of the most common diseases in elderly people. Risk factors that can cause hypertension are obesity and central obesity. That is caused by the lack of appropriateness of eating intake with activity in the elderly are declining. So there is a possibility of normal BMI and RLPP will reduce the risk of hypertension. This study aims to determine IMT and RLPP measurements as a predictor of hypertension. This type of research is observational with cross-sectional design and the number of research subjects is 71 elderly who suffer from hypertension and not hypertension. Sampling using total sampling method. Data analysis was done by univariate and bivariate analysis using chi-square test and logistic regression test. The result of statistic test showed that there was a correlation between body mass index with hypertension 0,002 ( $p<0,002)$ and BMI was risk factor proved by $R R 2,228(C I$ 1,333$3,723)$. There is a relationship between RLPP with hypertension $0.000(p<0.000)$ and $R L P P$ is hypertension risk factor with $R R$ value 4,340 (CI 1,896-9,933). The result of BMT logistic regression test is not a predictor of hypertension, but RLPP is a predictor to determine hypertension with the formula $Y=-3,614+2,285 X 1$. It is advisable for the elderly to maintain normal RLPP in order to reduce the risk of hypertension.
\end{abstract}

Keywords: Seniors, Hypertension, Body Mass Index, Waist and Waist Circumference.

Abstrak: Lanjut Usia, Hipertensi, Indeks Massa Tubuh, Rasio Lingkar Pinggang
dan Panggul. Masalah penyakit hipertensi merupakan salah satu penyakit yang sering
terjadi pada lanjut usia. Faktor resiko yang dapat menyebabkan terjadinya hipertensi
adalah kegemukan dan obesitas sentral. Yang disebabkan karena tidak kesesuaian
asupan makan dengan aktivitas pada lansia yang menurun. Sehingga terdapat
kemungkinan IMT dan RLPP normal akan mengurangi resiko terjadinya hipertensi.
Penelitian ini bertujuan untuk mengetahui pengukuruan IMT dan RLPP sebagai
prediktor hipertensi. Jenis penelitian bersifat observasional dengan desain cross-
sectional dan jumlah subjek peneliti adalah 71 lanjut usia yang menderita hipertensi dan
tidak hipertensi. Pengambilan sampel menggunakan metode total sampling. Analisa
data dilakukan dengan analisis univariat dan bivariat menggunakan uji chi-square dan
uji regresi logistic. Hasil uji statistik diperoleh ada hubungan antara indeks massa tubuh
dengan hipertensi 0,002 (p< 0,002) dan IMT merupakan faktor resiko dibuktikan
dengan nilai RR 2,228 (CI 1,333-3,723). Ada hubungan antara RLPP dengan hipertensi
0.000 (p< 0,000) dan RLPP merupakan faktor resiko hipertensi dengan nilai RR 4,340
(CI 1,896- 9,933). Hasil uji regresi logistik IMT bukan merupakan prediktor hipertensi,
tetapi RLPP merupakan prediktor untuk menentukan hipertensi dengan rumus Y= - 
$3,614+2,285 \mathrm{X}_{1}$. Sebaiknya untuk lanjut usia menjaga RLPP normal agar mengurangi resiko terjadi hipertensi.

Kata Kunci : Lanjut Usia, Hipertensi, Indeks Massa Tubuh, Rasio Lingkar Pinggang dan Panggul.

\section{PENDAHULUAN.}

Lanjut usia (lansia) adalah seseorang yang disebabkan usianya mengalami perubahan fisik, biologi dan fisik, jiwa dan sosial (Undang-undang No.32 Tahun 1992 tentang kesehatan). Lansia biasanya mengalami penurunan dan perubahan pada fungsi organ yang menyebabkan kemampuan tubuh untuk berkerja menjadi berkurang. Organ yang mengalami penurunan pada lansia yaitu sistem endokrin dan sistem imun (Fatmah, 2010).

Lansia mengalami penurunan fungsi organ yang menyebabkan masalah kesehatan yang sangat bervariasi, yang sangat berkaitan dengan degeneratif (manula) dan pada tubuh akan mulai kehilangan daya tahan tubuh secara progresif,ditambah dengan kemampuan fisik dan mental menurun sehingga tidak mampu melakukan pekerjaan yang berat kemudian tidak diimbangi dengan asupan makanan yang cukup sehingga cepat memudahkan untuk muncul beberapa penyakit pada lansia (Darmojo dan Martono,2006).

Penyakit pada lansia salah satunya hipertensi, terjadinya perubahan tekanan darah disebabkan salah satunya faktor umur, yang mempengaruhi perubahan setruktur atau kelenturan pada pembuluh darah besar. Hasil penelitian bahwa terjadi peningkatan tekanan darah sistolik sebesar $71,7 \%$ pada usia $>60$ tahun paling banyak lanjut usia 60-74 tahun di RW 01 Kunciran, Tangerang (Mardiana, 2014). Pada lansia akan terjadi peningkatan tekanan darah karena adanya peningkatan resistensi perifer dan aktivitas simpatik serta terjadi penurunan aktivitas pengaturan tekanan darah (reflek baroreseptor), hal ini disebabkan faktor umur pada lansia (Khomarun, 2013).

Pada lansia juga bisa disebabkan oleh pola makan yang salah yang dapat menyebabkan berat badan berlebih. Hal ini disebabkan oleh ketidaksesuaian antara asupan yang dikonsumsi lansia dengan kalori yang harus dikeluarkan sebagai energi yang digunakan untuk beraktifitas. Aktifitas fisik pada lansia berkurang karena faktor umur, sehingga banyak lansia yang mengalamikegemukan. Kegemukan dapat menjadi pencetus berbagai penyakit, misalnya penyakit jantung, diabetes millitus dan tekanan darah (Maryam dan Siti,2008).

Berdasarakan hasil penelitian menunjukan adanya hubungan positif yang signifikan antara IMT dengan tekanan darah sistolik dan diastolik pada orang yang memiliki BB lebih dan dibandingkan dengan yang memilki BB kurus, BB lebih akan berisiko mengalami peningkatan tekanan darah. Responden yang BB lebih memilliki peluang yang lebih besar mengalami hipertensi dibandingan responden yang memiliki Indeks massa tubuh kurang dari $25 \mathrm{~kg} / \mathrm{m} 2$ (Karel,2014). Hasil penelitian terdapat hubungan signifikan antara lingkar pinggang dan panggul dengan tekanan darah sistolik dan diastolik (Irene, 2014). National Heart, Lung and Blood Institute (2005) melaporkan bahwa responden yang 
mengalami hipertensi banyak ditemukan pada orang yang mengalami penumpukan lemak pada sekitar abdomen yang sering berhubungan signifikan dengan kejadian hipertensi.

Menurut WHO (World Health Organization) tahun 2013 penyakit kardiovaskular telah menyebabkan 17 juta kematian tiap tahun akibat komplikasi hipertensi yaitu sekitar 9,4 juta tiap tahun di seluruh dunia (A Global Brief on Hypertension, 2013). Berdasarkan data Riskesdas (2013), pravelensi hipertensi. pada tahun 2013 sebesar 9,5\%, merupakan suatu masalah yang terjadi di indonesia karena terjadi peningkatan pravelensi hipertensi dari 7,6\% tahun 2007 menjadi 9,5\% tahun 2013 .

Berdasarkan data Dinas Kesehatan Provinsi Jawa Tengah (2013), jumlah penderita hipertensi esensial sebanyak $554.771(67,57 \%)$ kasus. Jumlah kasus hipertensi laki-laki dan perempuan pada tahun 2015 di Karanganyar sebesar 25,28\%. Di Karanganyar prevalensi di Puskesmas Colomadu dengan jumlah responden laki laki yang mengalami hipertensi mencapai 5,9\%dan responden perempuan mencapai $31,37 \%$ (DKK Karanganyar, 2016).

Berdasarkan laporan hasil kegiatan Posyandu lansia di daerah Puskesmas Colomadu pada tahun 2016 bahwa di Desa Bolon banyak lansia yang menderita hipertensi yang tidak mengonsumsi obat antihipertensi (Laporan Posyandu Lansia Puskesmas Colomadu, 2016)

Berdasarkan hal hal yang diuraikan di atas penulis tertarik untuk meneliti IMT dan RLPP sebagai prediktor hipertensi pada lansia di Desa Bolon karena pravelensi hipertensi di daerah tersebut banyak lansia hipertensi yang tidak mengonsumsi obat antihipertensi, sedangkan obat antihipertensi merupakan penyebab terjadinya penurunan tekanan darah. Menurut (Irene, 2014; Novianingsih, 2012), bahwa hubungan IMT dan RLPP pada tekanan darah signifikan karena terdapat penumpukan lemak sekitar abdomen pada lingkar pinggang dan panggul merupakan resiko terkena hipertensi dengan berat badan lebih berpeluang tinggi menyebabkan tekanan darah tinggi.

\section{METODE PENELITIAN}

$\begin{array}{clr}\text { Jenis } & \begin{array}{l}\text { penelitian ini termasuk } \\ \text { penelitian }\end{array}\end{array}$ pendekatan cross-sectional di Posyandu Jetak dan Posyandu Bolon di Desa Bolon Kecamatan Colomadu Kabupaten Karanganyar pada bulan Februari sampai Juni 2017. Jumlah populasi pada penelitian ini yaitu 71 responden. Pengambilan sampel pada penelitian ini dilakukan dengan menggunakan dua teknik yaitu total sampling. Sampel yang digunakan harus memenuhi kriteria inklusi meliputi responden lanjut usia, dapat berdiri tegak (tidak bungkuk), responden baru yang didiagnosis hipertensi dan tidak mempunyai penyakit penyerta contoh penyakit ginjal, diabetes mellitus, jantung korener, responden yang sehat tidak mempunyai penyakit yang dapat mempengaruhi hipertensi seperti penyakit ginjal, diabetesmillitus, jantung koroner, responden yang tidak mengalami asites, edeman Extremitas, hepatomegali (pembesaran hati), Splenomegali (pembesaran limfa), responden yang tidak menjalani diet. Jumlah populasi pada penelitian ini yaitu 239 responden. Jumlah pada penelitian ini yaitu 71 responden.

Pengumpulan data status gizi diperoleh dari pengukuran antropometri berupa tinggi badan dan berat badan 
kemudian dihitung berdasarkan indeks massa tubuh (IMT) dihitung dengan cara berat badan dalam $\mathrm{kg}$ dibagi tinggi badan kuadrat dalam meter. Pengukuran tekanan darah diperoleh dengan menggunakan tensi meter (Sphigmomanometer) hasil dari pengukuran tekanan sistolik dan diastolik. Pengukuran rasio lingkar pinggang dan panggul (RLPP) diperoleh dengan menggunakan metlin untuk mengukur lingkar pinggang dan panggul, kemudian lingkar pinggang dibandingkan dengan lingkar panggul.

Analisis data menggunakan program SPSS for Windows versi 21.0. Data indeks massa tubuh dan rasio lingkar pinggang dan panggul sebagai prediktor hipertensi dianalisis menggunakan metode Chi Square. Interpretasinya adalah Jika $\mathrm{p}$ $\leq 0,05$ maka hipotesis diterima yang artinya ada hubungan. Jika $p>0,05$ maka hipotesis ditolak yang artinya tidak ada hubungan. Jika ada hubungan antara variabel dilakukan uji regresi logistik untuk mengetahui variabel merupakan prediktor hipertensi tidak.

\section{HASIL PENELITIAN}

Penelitian ini dilakukan di Posyandu Jetak dan Posyandu Bolon di Desa Bolon Kecamatan Colomadu Kabupaten Karangnyar. Jumlah penduduk Desa Bolon 37,922 jiwa dan jumlah lanjut usia 591 jiwa. Jumlah lanjut usia di Posyandu Jetak 89 dan di Posyandu Bolon 150.

\section{Analisis Univariat}

Pada penelitian ini responden berusia diatas 45 tahun. Responden yang digunakan untuk penelitian ini sebanyak 71 responden. Karakteristik responden berdasarkan jenis kelamin, umur, tekanan darah, indeks massa tubuh (IMT) dan rasio lingkar pinggang dan panggul ditampilkan pada Tabel 1.

\section{Tabel 1}

Distribusi Karateristik Responden

Berdasarkan Jenis Kelamin, Umur, Tekanan Darah, Indeks Massa Tubuh (Imt) Dan Rasio Lingkar Pinggang Dan Panggul (RLPP)

\begin{tabular}{|c|c|c|c|}
\hline \multicolumn{2}{|c|}{ Variabel } & Jumlah & $(\%)$ \\
\hline Jenis & Laki-laki & 4 & 5,6 \\
\hline kelamin & Perempuan & 67 & 94,4 \\
\hline \multirow[t]{3}{*}{ Umur } & $\begin{array}{l}\text { Usia } \\
\text { pertengahan } \\
\text { (45-59 tahun) }\end{array}$ & 21 & 29,6 \\
\hline & $\begin{array}{l}\text { Lanjut usia } \\
\text { (60-74 tahun) }\end{array}$ & 40 & 56,3 \\
\hline & $\begin{array}{l}\text { Lanjut usia tua } \\
\text { (75-90 tahun) }\end{array}$ & 10 & 14,1 \\
\hline \multirow[t]{2}{*}{$\begin{array}{l}\text { Tekanan } \\
\text { darah }\end{array}$} & $\begin{array}{l}\text { Hipertensi } \\
(>140 / 90 \\
\mathrm{mmHg})\end{array}$ & 33 & 46,5 \\
\hline & $\begin{array}{l}\text { Tidak hipertensi } \\
(<140 / 90 \\
\text { mmHg) }\end{array}$ & 38 & 53,5 \\
\hline \multirow[t]{2}{*}{ IMT } & $\begin{array}{l}\text { Gemuk }>25,0 \\
\mathrm{~kg} / \mathrm{m}^{2}\end{array}$ & 29 & 40,8 \\
\hline & $\begin{array}{l}\text { Tidak gemuk } \leq \\
25,0 \mathrm{~kg} / \mathrm{m}^{2}\end{array}$ & 42 & 59,2 \\
\hline \multirow[t]{2}{*}{ RLPP } & $\begin{array}{l}\text { Obesitas sentral } \\
\text { Perempuan } \\
>0,77 \\
\text { Laki-laki } \\
>0,9 \mathrm{~cm}\end{array}$ & 40 & 56,3 \\
\hline & $\begin{array}{l}\text { Tidak obesitas } \\
\text { sentral } \\
\text { Perempuan } \\
0,77 \mathrm{~cm} \text { Laki- } \\
\text { laki } 0,9 \mathrm{~cm}\end{array}$ & 31 & 43,7 \\
\hline
\end{tabular}

Berdasarkan tabel 1 diketahui jenis kelamin paling banyak adalah pada perempuan 67 lanjut usia yaitu sebesar $94,4 \%$. Untuk umur pada lanjut usia diketahui paling banyak pada umur usia lanjut 60-74 tahun yaitu sebesar 56,3\%. Karakteristik pada tekanan darah paling banyak pada tidak hipertensi tekanan darah <140/90 mmHg yaitu sebesar $53,5 \%$. Pada distribusi indeks massa tubuh 
(IMT) responden tidak gemuk paling banyak yaitu sebesar 59,2\% dan distribusi rasio lingkar pinggang dan panggul (RLPP) obesitas sentral jumlah paling banyak yaitu sebesar 56,7.

1.1.1

Analisa Bivariat

\section{Hubungan Indeks Massa Tubuh dengan Hipertensi}

Hasil hubungan indeks massa tubuh dengan hipertensi ditampilkan pada tabel 2.

Tabel 2.

Hubungan Indeks Massa Tubuh Dengan Hipertensi

\begin{tabular}{|c|c|c|c|c|c|c|c|}
\hline \multirow{3}{*}{$\begin{array}{l}\text { Indeks } \\
\text { massa } \\
\text { tubuh }\end{array}$} & \multicolumn{4}{|c|}{ Hipertensi } & \multicolumn{2}{|c|}{ Total } & \multirow{3}{*}{$\begin{array}{l}R R \\
(95 \% C I)\end{array}$} \\
\hline & \multicolumn{2}{|c|}{$\mathrm{Ya}$} & \multicolumn{2}{|c|}{ Tidak } & \multirow[b]{2}{*}{$\mathrm{n}$} & \multirow[b]{2}{*}{$\%$} & \\
\hline & $\mathrm{n}$ & $\%$ & $\mathrm{n}$ & $\%$ & & & \\
\hline Gemuk & 20 & 69 & 9 & 31 & 29 & 100 & 2.228 \\
\hline $\begin{array}{l}\text { Tidak } \\
\text { gemuk }\end{array}$ & 13 & 31 & 29 & 69 & 42 & 100 & $\begin{array}{l}(1,333- \\
3,723)\end{array}$ \\
\hline Total & 33 & 46,5 & 38 & 53,5 & 71 & 100 & \\
\hline
\end{tabular}

bahwa dari 29 responden yang memiliki IMT kategori gemuk terdapat $20(69 \%)$ responden yang memilki penyakit hipertensi. Dari 42 responden yang memilliki IMT kategori tidak gemuk sebanyak $13(31 \%)$ responden yang memilki penyakit hipertensi. Dari hasil uji statistik (chi-square) didapatkan p-value sebesar 0,002 (lebih kecil dari pada $\alpha=0,05)$. Maka $\mathrm{H} 0$ ditolak dan H1 diterima artinya terdapat hubungan antara indeks massa tubuh dengan kejadian hipertensi pada Posyandu lansia Jetak dan Posyandu lansia Bolon di Desa Bolon, Kecamatan Colomadu, Kabupaten Karanganyar. Dari analisis nilai Relative Risk (RR) diketahui nilai RR sebesar 2,228 (CI1,333-3,723), sehingga kesimpulan Indeks Massa Tubuh merupakan faktor resiko menyebabkan penyakit Hipertensi. Kemudian responden yang memiliki IMT kategori gemuk memiliki peluang hipertensi 2,228 kali dari pada responden yang memiliki IMT kategori tidak gemuk.

Hubungan rasio lingkar pinggang dan panggul dengan hipertensi

Hasil hubungan rasio lingkar pinggang dan panggul ditampilkan pada tabel 3 .

Tabel 3

Hubungan Rasio Lingkar Pinggang Dan Panggul Dengan Hipertensi

\begin{tabular}{|c|c|c|c|c|c|c|}
\hline \multirow{2}{*}{$\begin{array}{l}\text { Rasio lingkar } \\
\text { pinggang dan } \\
\text { panggul }\end{array}$} & \multicolumn{4}{|c|}{ Hipertensi } & \multicolumn{2}{|c|}{ Total } \\
\hline & & $\mathrm{a}$ & & & & \\
\hline$P$ value & $\mathrm{n}$ & $\%$ & $\mathrm{n}$ & $\%$ & $\mathrm{n}$ & $\%$ \\
\hline Obesitas & 28 & 70 & 12 & 30 & 40 & 100 \\
\hline $\begin{array}{l}\text { Tidak obesitas } \\
\text { sentral }\end{array}$ & 5 & 16,1 & 26 & 83,9 & 31 & 100 \\
\hline Total & 33 & 46,5 & 38 & 53,5 & 71 & 100 \\
\hline$R R, 002$ & $P$ & & & & & \\
\hline$(95 \%$ & val & & & & & \\
\hline CI) & ue & & & & & \\
\hline & & & & & & \\
\hline $\begin{array}{c}, 340(1,896- \\
9,933)\end{array}$ & $\begin{array}{c}0,0 \\
00\end{array}$ & & & & & \\
\hline
\end{tabular}

Berdasarkan tabel 3, diketahui bahwa dari 40 responden yang memiliki rasio lingkar pinggang dan panggul kategori obesitas sentral terdapat 28 (70\%) responden yang hipertensi. Dari 31 responden yang memiliki rasio lingkar pinggang dan panggul kategori tidak obesitas sentral terdapat $5 \quad(16,1 \%)$ responden hipertensi. Dari hasil uji statistik (chi square) didapatkan nilai $\mathrm{p}$ sebesar 0,000 (lebih kecil dari pada nilai $\alpha=0,05)$. Hal ini berarti terdapat hubungan hipertensi pada responden yang memiliki rasio lingkar pinggang dan panggul kategori obesitas sentral. Dari hasil analisis dihasilkan nilai Relative Risk sebesar 4,340 (CI 1,896-9,933) sehingga 
kesimpulan rasio lingkar pinggang panggul merupakan faktor resiko yang menyebabkan terjadinya hipertensi. Kemudian responden yang memiliki rasio lingkar pinggang dan panggul kategori berisiko obesitas sentral memiliki peluang hipertensi 4,340 kali dari pada responden yang memiliki lingkar pinggang kategori normal.

\section{Analisis Uji Regresi Pemilihan Variabel Kandidat Uji Regresi}

Didalam penelitian ini terdapat 2 variabel yang di duga berpengaruh dengan penyakit hipertensi yaitu Indeks Massa Tubuh (IMT) dan Rasio Lingkar Pinggang dan Panggul (RLPP). Untuk mendapatkan model uji regresi terlebih dahulu dilakukan analisis bivarat yaitu antara 2 variabel IMT dan RLPP dengan penyakit hipertensi. Variabel yang memiliki nilai $\mathrm{p}$ $<0,25$, maka dapat dijadikan kandidat yang akan dimasukan ke dalam model uji regresi ditahap selanjutnya. Hasil uji hubungan dapat dilihat pada tabel sebelumnya tabel 2 dan 3 .

\section{Pembuatan Model Faktor Resiko Hipertensi}

Analisis regresi mempunyai tujuan yaitu untuk mendapatkan model yang terbaik dalam menentukan determinan penyakit hipertensi. Analisis yang digunakan untuk penelitian ini adalah uji regresi logistik karena variabel terikat dan variabel bebasnya merupakan variabel kategorik yang dikotom. Berdasarkan hasil analisis faktor resiko hipertensi yaitu IMT dan RLPP karena 2 variabel tersebut memiliki nilai $\mathrm{p}<0,25$. Hasil uji regresi indeks massa tubuh (IMT) dan rasio lingkar pinggang dan panggul (RLPP) dapat dilihat pada tabel 4
Tabel 4

Variabel berdasarkan Faktor Resiko Hipertensi

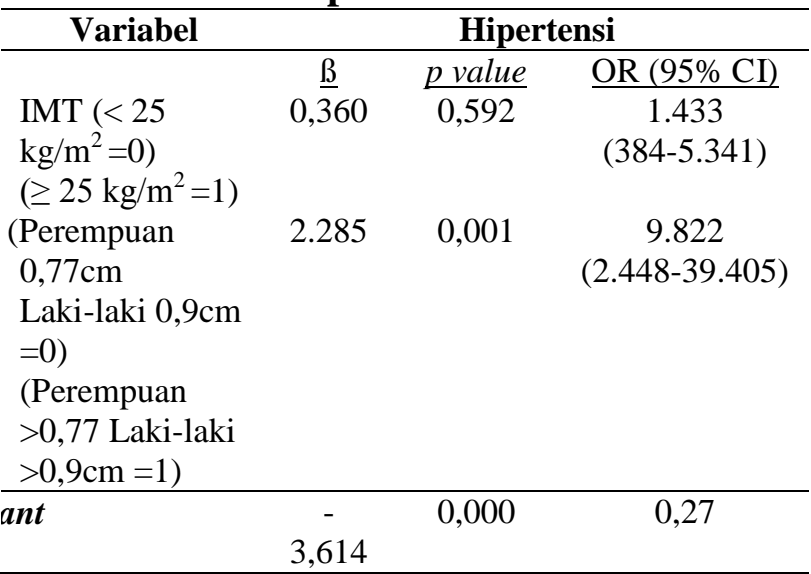

Pada tabel 4 dapat diketahui bahwa hanya variabel RLPP yang menunjukan hasil yang signifikan ( $\mathrm{p}$ $<0,05)$ dan untuk variabel IMT tidak menunjukan hasil yang signifikan. Dari hasil tersebut dapat diketahui bahwa rasio lingkar pinggang dan panggul secara signifikan berpengaruh terhadap kejadian hipertensi pada lanjut usia. Model regresi yang diperoleh adalah sebagai berikut:

$Y=-3,614+2.285 X_{1}$

Keterangan:

Y: Status Hipertensi

$\mathrm{X}_{1}$ : Rasio Lingkar Pinggan dan Panggul (RLPP)

Maka jika terdapat seseorang dengan kriteria $\mathrm{X}_{1}=$ obesitas sentral, RLPP lakilaki $>0,90$ dan perempuan 0,77 (nilai 1 ), maka kemungkinan terjadi hipertensi adalah

$\mathrm{Z}=-3,614+2,285 \mathrm{X}_{1}$

$Z=-3,614+2,285(1)$

$\mathrm{Z}=-1.329$

Sehingga $p=E\left(Y=\frac{1}{X_{i}}\right) \frac{1}{1 e^{\left(01 X_{1}\right)}}$ atau $p=$ $E\left(Y=\frac{1}{X_{i}}\right) \frac{1}{1+e^{-(z)}}$

Besar $\mathrm{Z}=-1.329$ dengan $\boldsymbol{e}$ bilangan natural yaitu 2,718 , maka: 
$p=E\left(Y=\frac{1}{X_{i}}\right) \frac{1}{1+e^{-(z)}}$

$p=p=E\left(Y=\frac{1}{X_{i}}\right) \frac{1}{1+e^{-(-1.329)}}$

$p=E\left(Y=\frac{1}{X_{i}}\right) \frac{1}{4,777}$

$p=E\left(Y=\frac{1}{X_{i}}\right)=0,209$

Jadi seseorang dengan kriteria obesitas sentral perempuan $>0,07$ dan laki-laki > 0,9 maka berisiko 20,9\% menderita hipertensi. Untuk seseorang dengan kriteria $X_{1}=$ tidak obesitas sentral, RLP perempuan $<0,77$ dan laki-laki $<0,9$ (0), maka kemungkinan menderita hipertensi adalah:

$\mathrm{Z}=-3,614+2,285 \mathrm{X}_{0}$

$Z=-3,614+2,285(0)$

$Z=-3.614$

Besar $\mathrm{Z}=-3,614$ dengan $\boldsymbol{e}$ bilangan natural yaitu 2,718 , maka:

$p=E\left(Y=\frac{1}{X_{i}}\right) \frac{1}{1+e^{-(z)}}$

$p=p=E\left(Y=\frac{1}{X_{i}}\right) \frac{1}{1+e^{-(-3.614)}}$

$p=E\left(Y=\frac{1}{X_{i}}\right) \frac{1}{38,1}$

$p=E\left(Y=\frac{1}{X_{i}}\right)=0,026$

Jadi seseorang dengan kriteria tidak obesitas sentral, beresiko 2,6\% menderita hipertensi. Dari hasil regresi diatas bahwa orang yang menderita obesitas sentral dapat memprediksi 20,9\% lebih besar mengalami hipertensi dibandingkan dengan orang yang tidak obesitas sentral lebih rendah yaitu $2,6 \%$.

\section{PEMBAHASAN}

\section{Hubungan Indeks Massa Tubuh dengan Hipertensi}

Dapat dilihat pada tabel 2 bahwa ada hubungan antara IMT dengan hipetensi pada lanjut usia dengan nilai $\mathrm{p}$ $0,002(<0,05)$. Hal ini sejalan dengan penelitian yang dilakukan oleh Kurniawati (2008) yaitu bahwa ada hubungan signifikan antara IMT dengan tekanan darah pada usia lanjut di Kota Palu. Usia lanjut 1,5 kali beresiko mengalami tekanan darah tinggi yaitu lansia dengan IMT $\geq 25$ dibanding dengan lansia dengan IMT <25 setelah dikontrol faktor jenis kelamin, riwayat tekanan darah keluarga dan stress.

Indeks massa tubuh dalam penelitian ini juga merupakan faktor resiko hipertensi yaitu didapatkan nilai RR 2,228 (CI1,333-3,723), yang dimana nilai $\mathrm{RR}>1$ maka orang yang mengalami IMT lebih akan lebih beresiko mengalami hipetensi 2,228 kali lebih besar mengalami hipertensi dibandingkan dengan orang yang IMT tidak gemuk. Penelitian ini juga didukung dengan penelitian sebelumnya (Nissan,2014) yaitu ada hubungan IMT dengan tekanan darah dengan nilai ( $p$ value $=0,001$ ). Responden yang mengalami kegemukan sebesar $64,7 \%$ lebih beresiko mengalami peningkatan tekanan darah sebanyak 4,97 kali lebih besar dari pada responden yang memeliki IMT normal.

Indeks massa tubuh yang lebih atau kegemukan memiliki hubungan dengan kejadian hipertensi. Rata-rata orang yang mengalami kegemukan bisa meningkatkan tekanan darah (hipertensi) hal ini dikarenakan meningkatnya aktivasi sistem saraf simpatis dan RAA (Renin Angiotensin-Aldosteron) yang berlebihan yang dimana dapat meningkatkan risiko peningkatan tekanan darah (Fatimawali, 2013). Pada orang yang mengalami kelebihan berat badan akan terjadi peningkatan jaringan adiposa, kemudian jaringan adiposa yang meningkat terus menerus dapat menyebabkan meningkatnya Sistem RAA sehingga membuat terjadi peningkatan reabsorbsi natrium ginjal. Peningkatan reabsorbsi 
ginjal membuat meningkatnya aktivitas sistem saraf simpatis. Regulasi oleh saraf simpatis dengan jarak waktu yang pendek akan meningkatkan curah jantung (cardiac output) dan vasokonstriksi peripheral, curah jantung yang meningkat membuat tekanan darah naik maka terajadi penyakit hipertensi (Romayne, 2011).

Hasil penelitian Tesfaye F (2007) tekanan darah meningkat dengan bertambahnya indeks massa tubuh, resiko hipertensi lebih tinggi pada orang dengan IMT $25 \mathrm{~kg} / \mathrm{m}^{2}$. Didapatkan hasil yang signifikan bahwa ada hubungan yang positif antara IMT dengan tekanan darah pada 3 populasi yaitu di Ethiopia, Vietnam dan Indonesia. Hasil penelitian Juhi Gupta (2016) ada hubungan IMT dengan hipertensi di rumah sakit Rural Teaching yaitu ada peningkatan yang signifikan IMT yang meningkat maka tekanan darah semakin meningkat dengan nilai $\mathrm{p}<0,05$.

Hubungan rasio lingkar pinggang dan panggul dengan hipertensi

Hasil dari tabel 3 diatas bahwahda3 hubungan antara RLPP dengan hepertensi dengan hasil nilai p 0,000. Hal ini sejalan dengan penelitian Hananta dan Freitag, (2011) bahwa obesitas yang lebih berpengaruh terhadap kejadian hipertensi adalah obesitas sentral atau obesitas pusat. Obesitas sentral secara positif telah dikorelasikan dengan hipertensi pada beberapa populasi. Secara teori, obesitas memiliki hubungan dengan kejadian hipertensi. Hasil juga didukung oleh penelitian Setyaningsih (2013), Putri (2013), Pradana (2010), mendapatkan hasil penelitian yang signifikan yaitu adanya hubungan antara lingkar pinggang dengan tekanan darah dengan nilai $p$ - value $(p<0,05)$. Menurut Menurut Irine (2014) obesitas sentral ini disebabkan oleh penumpukan lemak disekitar abdomen yang menjadi penyebab yang signifikan dengan kejadian hipertensi dengan nilai $\mathrm{p}$ $(\mathrm{p}<0,01)$.

Menurut Janssen, dkk (2004) obesitas berhubungan dengan tekanan darah tinggi, meskipun penyebabnya belum sepenuhnya diketahui. Salah satu mekanismenya mungkin dalam terlibat dalam pengaruh obesitas sentral pada tekanan darah melibatkan pengurangan sensivitas insulin, dengan perkembangan selanjutnya kompensansi hiperinsulinemia. Sekresi insulin yang berlebihan, yang telah diamati pada obesitas dan terlihat dihubungkan dengan adanya lemak intra-abdominal, diduga meningkatkan retensi sodium dan cairan yang akan menstimulus aktivitas simpatik, dan akhirnya akan meningkatkan tekanan darah. Hasil penelitian Badaruddoza (2010) ada hubungan yang signifikan antara IMT, RLPP dan lipatan kulit dengan nilai $\mathrm{p}<0.05$.

\section{Model faktor resiko hipertensi}

Hasil uji regresi logistik pada tabel 4 bahwa yang menujukan hasil signifikan hanya RLPP dengan hipertensi yaitu dengan nilai p 0,001 $(<0,05)$. Kemudian dapat disimpulkan bahwa RLPP merupakan prediktor untuk hipertensi dengan rumus regresi logistik $\mathbf{Y}=\mathbf{- 3 , 6 1 4 +}$ $\mathbf{2 . 2 8 5 X}_{1}$. Dari perhitungan rumus regresi didapatkan hasil bahwa orang yang mengalami obesitas sentral maka akan diprediksi beresiko lebih besar hipetensi $20,9 \%$ dibandingkan dengan orang yang tidak hipertensi. 


\section{KESIMPULAN DAN SARAN}

Pravelensi responden lanjut usia di Posyandu Jetak dan Posyandu Bolon di Desa Bolon Kecamatan Colomadu Kabupaten Karanganyar berdasarakan pengukuran indeks massa tubuh, responden dalam kategori gemuk $42 \%$. Berdasarkan pengukuran rasio lingkar pinggang dan panggul responden dalam kategori obesitas sentral $40 \%$. Ada hubungan antara indeks massa tubuh dan rasio lingkar pinggang dan panggul dengan hipertensi pada lanjut usia di Posyandu Jetak dan Posyandu Bolon di Desa Bolon Kecamatan Colomadu Kabupaten Karanganyar. Hasil uji regresi indeks massa tubuh tidak dapat dijadikan prediktor, bahwa hanya rasio lingkar pinggang dan panggul yang dapat dijadikan sebagai prediktor hipertensi dengan rumus $\mathrm{Y}=-3,614+2,285 \mathrm{X}_{1}$. Ibu bidan atau petugas kesehatan setempat lebih aktif untuk memberikan pengarah dan penyuluhan tentang pentingnya menjaga pola makan yang baik agar tidak obesitas atau tidak obesitas sentral sehingga lanjut usia bisa mengurangi resiko menderita penyakit hipertensi.

Sebaikan lanjut usia rajin memantau berat badan sehingga tetap menjaga berat badan tubuh normal, dengan cara mejaga pola makan yang seimbang dengan aktifias fisik lanjut usia. Hal ini agar tidak mengalami obesitas sentral maupun kegemukan untuk mengurangi resiko terkena penyakit hipertensi.

\section{DAFTAR RUJUKAN}

Badaruddoza, Navneet Kaur dan Basanti Barna. (2010). Inter-relationship of waist-to-hip ratio (WHR), body mass index (BMI) and subcutaneous fat with blood pressure among university-going Punjabi Sikh and Hindu females. Department of Human Genetics. Guru Nanak Dev University. Amritsar. Punjab. India

Darmojo, Boedhi dan Hadi Martono. (2006). Buku Ajar Geriatri. Ilmu KesehatanUsia Lanjut. Jakarta. Fakultas Kedokteran. Universitas Indonesia.

Fatmah.2010. Gizi Usia Lanjut. Erlangga : jakarta.

Fatimawali, Tooy R, Manampiring A.2013. Gambaran Tekanan Darah pada Remaja Obes di Kabupaten Minahasa. e-Biomedik (eBM): 1:951-5

F Tesfaye1, Dkk. 2007. Association between body mass index and blood pressure across three populations in Africa and Asia. Department of Community Health, Faculty of Medicine, Addis Ababa University, Addis Ababa, Ethiopia.

Hananta, Y dan Freitag, H. 2011. Deteksi Dini dan Pencegahan Hipertensi dan Stroke. Media Pressindo. Yogyakarta.

Irene Moudy Sumayku., Karel Pandelaki.,M.C.P.Wongkar. 2014. Hubungan Indeks Massa Tubuh dan Lingkar Pinggang dengan Tekanan Darah Pada Mahasiswa Fakultas Kedokteran Universitas Sam Ratulangi. Fakultas Kedokteran Universitas Sam Ratulangi Manado. Jurnal $e$ CliniC (eCl). Manado

Janssen, Ian, et.al (2004) Waist Circumference and Not Body Mass Index Explain obesity Related Health. American Journal of Clinical Nutrition Vol 79: 379-84. 
Juhi Gupta, Dkk (2016). Study Of Association Between Body Mass Index And Hypertension In Elderly In A Rural Teaching Hospital. Department of Medicine, Jawahar Lal Nehru Medical College, DMIMS, Sawangi. Wardha.

Khomarun, Endang Sri Wahyuni, Maharso Adhi Nugroho. 2013. Pengaruh Aktifitas Fisik Jalan Pagi Terhadap Penurunan Tekanan Darah Pada Lansia dengan Hipertensi Stadium I di Posyandu Lansia Desa Makam Haji. Kementrian Kesehatan Politeknik Kesehatan Surakarta Jurusan Okupasi Terapi: Surakarta

Kurniawati, 2008. Hubungan Status Gizi dengan Hipertensi pada Usia Lanjut di Kota Palu Sulawesi Tengah..Abstrak. Program Pascasarjana Fakultas Kedokteran Universitas Gajah Mada Yogyakarta

L. Romayne Kurukulasuriya, Sameer Stas, dkk. 2011. Hypertension in Obesity. Elsevier

Maryam, R.S., et al., 2008, Mengenal Usia Lanjut dan Perawatannya. Jakarta: Salemba Medika

Meilaningrum, Putri Rahayu. 2013. Hubungan Beberapa Indikator Obesitas dengan Tekanan Darah pada Usia Dewasa di Kecamatan Kedungkandang Kota Malang. Universitas Brawijaya Malang: Program Studi Ilmu Gizi Fakultas Kedokteran.

Novianingsih E. 2012. Hubungan beberapa indikator status gizi dengan tekanan darah pada remaja. Fakultas kedokteran universitas Diponegoro
Nissan Marwadias, Amalina Tri Susilani, Dwi Ratnaningsih. 2014. Hubungan Indeks Massa Tubuh dan Lingkar Pinggang dengan Tekanan Darah Pada Wanita Dewasa di Dusun Kalibang Desa Wonokerto Kecamatan Wonogiri Kabupaten Wonogiri Propinsi Jawa Tengah Tahun 2014. Jurnal Permata Indonesia: Wonogiri.

Setyaningsih, Upik. 2013. Hubungan Indeks Massa Tubuh dan Rasio Lingkar Pinggang Panggul dengan Tekanan Darah pada Pasien Hipertensi Rawat Jalan di RS Tugurejo Semarang. Universitas Muhammadiyah Semarang. Program Studi Ilmu Gizi: Semarang

Riset Kesehatan Dasar (Riskesdas). Badan Penelitian dan Pengembangan Kesehatan Kementrian Kesehatan RI tahun 2013

World Health Organization, 2013. WHO"s Global Brief on Hypertension: Silent killer, global public health crisis.

Yanih Mardiana dan Zelfino. 2014. Hubungan Antara Tingkat Stres Lansia dan Kejadian Hipertensi Pada Lansia di RW 01 Kunciran Tangerang. Fakultas Ilmu Kesehatan. Universitas Esa Unggul: 